\begin{abstract}
Iranica
Abstracta Iranica Revue bibliographique pour le domaine irano-aryen

Volume 32-33 | 2013

Comptes rendus des publications de 2009-2010
\end{abstract}

\title{
Nina G. Garsoïan. Studies on the Formation of Christian Armenia
}

\section{Christelle Jullien}

\section{(2) OpenEdition}

12 Journals

\section{Édition électronique}

URL : http://journals.openedition.org/abstractairanica/40827

DOI : 10.4000/abstractairanica.40827

ISSN : 1961-960X

Éditeur :

CNRS (UMR 7528 Mondes iraniens et indiens), Éditions de l'IFRI

\section{Édition imprimée}

Date de publication : 1 décembre 2013

ISSN : 0240-8910

\section{Référence électronique}

Christelle Jullien, "Nina G. Garsoïan. Studies on the Formation of Christian Armenia », Abstracta Iranica [En ligne], Volume 32-33 | 2013, document 322, mis en ligne le 01 juillet 2016, consulté le 26 septembre 2020. URL : http://journals.openedition.org/abstractairanica/40827 ; DOI : https://doi.org/ $10.4000 / a b s t r a c t a i r a n i c a .40827$

Ce document a été généré automatiquement le 26 septembre 2020.

Tous droits réservés 


\title{
Nina G. Garsoïan. Studies on the Formation of Christian Armenia
}

\author{
Christelle Jullien
}

\section{RÉFÉRENCE}

Nina G. Garsoïan. Studies on the Formation of Christian Armenia. Aldershot, Ashgate, 2010, 300 p. (Variorum Collected Studies Series CS 959).

1 Ce volume constitue le troisième volet des Opera minora de l'A. Il propose une sélection d'articles des dix dernières années, dont la thématique centrale est dévolue à la période de ce que l'A. propose d'appeler l'« Interrègne", période qui sépare les Arsacides des Bagratides, et plus spécifiquement à l'intérieur de cette période le $\mathrm{VI}^{\mathrm{e}}$ jusqu'à la première moitié du VIII siècle (II). L'A. montre la diversité des forces politiques dans la consolidation de l'identité arménienne en tant que nation. Elle souligne (VI) l'importance de considérer l'histoire du développement de l'Église arménienne dans ses connexions avec les mouvements missionnaires et d'échanges venus des communautés chrétiennes des empires perse et byzantin voisins, refusant l'idée d'une trajectoire unilatérale. La mention des provinces ecclésiastiques d'Arzanène, de Cordouène ou de Zabdicène (représentant les satrapies orientales), à la fois dans les énumérations de juridiction arménienne et dans les actes synodaux de l'Église de Perse (en particulier en 410) vient illustrer la perception transeuphratéenne de l'Église arménienne dans le cadre politique de la Grande Arménie. L'A. développe par ailleurs les liens transculturels établis entre les milieux syriaque et arménien (VII). 


\section{AUTEURS}

\section{CHRISTELLE JULLIEN}

CNRS, Mondes iranien et indien, Paris 